\title{
Еластографія зсувної хвилі в оцінці морфологічних змін підшлункової залози при хронічному панкреатиті
}

\author{
О. М. Бабій, Б. Ф. Шевченко, І. С. Коненко, Н. Г. Гравіровська, Н. Ю. Ошмянська, С. В. Ущина
}

Інститут гастроентерології НАМН України, м. Дніпро

\section{Elastography of a shift wave in estimation of morphological changes in pancreatic gland in chronic pancreatitis}

\author{
O. M. Babii, B. F. Shevchenko, I. S. Konenko, N. G. Gravirovskya, N. Yu. Oshmyanskya, \\ S. V. Ushchina \\ Institute of Gastroenterology, Dnipro
}

\begin{abstract}
Peферат
Мета. Встановити чутливість і специфічність еластографії зсувної хвилі в оцінці морфологічних змін підшлункової залози (ПЗ) при хронічному панкреатиті (ХП).

Матеріали і методи. Проведено ретроспективний аналіз доопераційних результатів еластографії зсувної хвилі 3 даними морфологічних досліджень біоптатів ПЗ, отриманих у 68 пацієнтів, оперованих 3 приводу ускладнень ХП (основна група), і 30 пацієнтів без ознак ХП (контрольна група).

Результати. Застосування методу еластографії зсувної хвилі в оцінці морфологічних змін ПЗ при ХП дало змогу розробити діагностичну модель високої якості з чутливістю 80,1\% і специфічністю 86,4\%. За кольоровим патерном та показниками жорсткості паренхіми ПЗ верифіковано морфологічні зміни органа в стадії раннього і пізнього фіброзу на тлі активного та неактивного запалення його паренхіми.

Висновки. Виділені найбільш достовірні цифрові показники еластографії зсувної хвилі в неінвазивній оцінці активності запалення та стадії фіброзної трансформації ПЗ при ХП.

Ключові слова: підшлункова залоза; хронічний панкреатит; фіброз; запалення; еластографія зсувної хвилі; морфологія Abstract

Objective. To establish the sensitivity and specificity of elastography of the shift wave in estimation of morphological changes in pancreatic gland in chronic pancreatitis.

Materials and methods. Retrospective analysis of the preoperative elastography results, concerning the shift wave, was accomplished, using the morphological investigations data from the pancreatic gland biopsies, obtained in 68 patients, operated on for complications of chronic pancreatitis (the main group), and in 30 patients, not owing the chronic pancreatitis signs (control group). Results. Application of elastographic the shift wave procedure in estimation of morphologic pancreatic changes in chronic pancreatitis made it possible to elaborate a diagnostic pattern of a high quality with sensitivity $80.1 \%$ and specificity $86.4 \%$. Morphological changes in the organ in stages of early and late fibrosis on background of active and nonactive inflammation of its parenchyma were verified in accordance to a color pattern and indices of the pancreatic parenchyma rigidity.

Conclusion. The most trustworthy numeral indices of elastography of a shift wave were delineated in noninvasive estimation of the inflammation activity and a stage of the pancreatic fibrous transformation degree in chronic pancreatitis.

Keywords: pancreatic gland; chronic pancreatitis; fibrosis; inflammation; elastography of a shift wave; morphology.
\end{abstract}

Модернізація різних методів візуалізації підшлункової залози (ПЗ) орієнтована на максимально можливу оцінку морфологічних змін в ії паренхімі. В останні роки розроблено методи, за допомогою яких можливо оцінити структуру тканини ПЗ за іiі «жорсткістю» та «еластичністю» $[1,2]$. Один із таких методів - еластографія зсувної хвилі (ЕЗХ) (Shear Wave Elastography - SWE), в основі якого лежить принцип збудження в тканинах ультразвуковим променем поперечних зсувних хвиль і реєстрації швидкості їх поширення другим зондуючим ультразвуковим променем. Швидкість поширення хвиль тим вище, чим вище жорсткість тканини. Кількісно результат ЕЗХ виражають у вигляді або показників швидкості зсувних хвиль в м/с, або модуля пружності Юнга в кілопаскалях (кПа). Доведено, що жорсткість паренхіматозних органів корелює з їх фіброзною трансформацією [1 - 3]. На даний час можливості ЕЗХ активно використовують в діагнос- тиці злоякісних утворень різної локалізації. $Є$ публікації про успішне застосування цього методу для визначення ступеня фіброзу печінки [4]. Однак питання діагностики хронічного панкреатиту (ХП) за допомогою транскутанної Е3Х ПЗ висвітлені лише в поодиноких зарубіжних роботах [5 - 9]. Вітчизняних досліджень щодо ЕЗХ ПЗ майже немає [10]. Лише в одному вагомому вітчизняному дослідженні порівняно інтраопераційні дані пальпації ПЗ 3 даними компресійної еластометрії. Встановлено прямий кореляційний зв'язок ( $\mathrm{r}=0,75 ; \mathrm{p}<0,01)$ між пальпаторною та еластометричною твердістю головки ПЗ, а також прямий сильний кореляційний зв'язок між пальпаторною та еластометричною твердістю тіла і хвоста ПЗ ( $\mathrm{r}=0,87$ і 0,83 відповідно; $\mathrm{p}<0,01$ ). За даними авторів, твердість ПЗ та ускладнення ХП - дві ознаки, за якими визначають основну клінічну симптоматику, вибір операції і тяжкість ХП [11]. 
Знання локалізації і обсягу трансформованої тканини ПЗ при ХП наближає до селективності застосування органозберігаючих операцій за рахунок чіткого визначення зон паренхіми ПЗ, що підлягають резекції. У цьому плані становить інтерес порівняльний аналіз показників Е3Х і морфологічних даних стадії фіброзної трансформації та запалення ПЗ при ХП.

Мета дослідження: встановити чутливість і специфічність ЕЗХ в оцінці морфологічних змін ПЗ при ХП.

\section{Матеріали і методи дослідження}

Проведено ретроспективний аналіз результатів обстеження і лікування 68 пацієнтів з ускладненим ХП, оперованих у відділенні хірургії органів травлення Інституту з січня 2013 по грудень 2016 р. Чоловіків було 47 (69,1\%), жінок - 21 (30,9\%) у віці 26 - 76 років, середній вік пацієнтів становив $(46,1 \pm 3,4)$ року.

Показаннями до виконання хірургічних втручань були: постійний або рецидивуючий больовий синдром, протокова панкреатична гіпертензія, вірсунгодилатація, вірсунголітіаз, стриктури головної протоки ПЗ, кальциноз панкреатичної паренхіми, стеноз термінального відділу загальної жовчної протоки з обтураційною жовтяницею та/або дванадцятипалої кишки (дуоденальна непрохідність), постнекротичні кісти, портальна гіпертензія, нориці ПЗ. Контрольну групу склали 30 пацієнтів без ознак ХП. Порівняно доопераційні результати Е3Х з даними морфологічного дослідження біоптатів ПЗ, отриманих інтраопераційно.

Ультразвукову еластографію та еластометрію ПЗ проводили транскутанним доступом методом ЕЗХ за допомогою датчика для конвексного сканування з частотою 1 - 5 МГц, використовуючи ультразвуковий сканер «SONEUS P7» (Харків, Україна). Консистенцію ПЗ оцінювали за характером кольорового картування і його розподілом за шкалою «blue-light - blue - green - yellow - red color». Жорсткість тканини ПЗ за ЕЗХ оцінювали в кПа. Для цього проводили не менше двох вимірювань ЕЗХ у ділянці головки, тіла і хвоста ПЗ. Отримані показники порівнювали з даними ЕЗХ здорових осіб, щодо яких середній показник жорсткості дорівнював 3,2 - 4,38 кПа, $(3,88 \pm 0,43)$ кПа без достовірної відмінності між показниками жорсткості анатомічних відділів органа: головка - $(4,05 \pm 0,33)$ кПа, тіло - $(3,86 \pm 0,46)$ кПа, хвіст - $(3,73 \pm 0,53)$ кПа.

Проводили морфологічні дослідження біоптатів анатомічних відділів ПЗ (головка, тіло, хвіст), які забирали під час планових операцій. Оцінюючи морфологічний стан ПЗ при ХП, акцентували на визначенні ступеня фіброзу за M. Stolte [12] та активності запалення паренхіми (нейтрофільна або лімфоплазмоцитарна інфільтрація). За допомогою комп'ютерної морфометрії визначали співвідношення площі фіброзної тканини до загальної площі біоптата, застосовуючи програму Image J 1.45S («National Institutes of Health», USA). Розраховували статистичні дані за допомогою програмного пакета MedCalc v12.7.0.0 Craced-EAT.

Статистичне опрацювання результатів досліджень здійснювали методами варіаційної статистики, реалізованими стандартним пакетом прикладних програм SPSS 13.0 for Windows. Різницю вважали достовірною, якщо досягнутий рівень значущості (р) був нижчим за 0,05. Кореляційний аналіз проводили за Спірменом. Ефективність діагностики оцінювали за допомогою ROC-аналізу (Receiver Operating Characteristic) (побудова ROC-кривої) щодо різних типів розподілу значень показників. Інформативність показника оцінювали за величиною площі під ROC-кривою (Area under the ROC Curve - AUC). Чим ближче крива до діагоналі $(\mathrm{AUC}=0,5)$, тим нижче діагностична цінність показника; чим ближче площа під кривою до 1, тим ефективніше діагностичний тест.

\section{Результати}

За даними гістологічного дослідження біоптатів ПЗ, отриманих під час хірургічного втручання, достовірну різницю (р < 0,05) фіброзної трансформації паренхіми ПЗ спостерігали тільки в поєднанні морфометричних показників I та II ступеня фіброзу П3 - (20,57 $\pm 3,52) \% 3$ морфометричними показниками III та IV ступеня фіброзу П3 - (73,02 $\pm 3,33) \%$, тому в подальшому дослідженні проводили порівняльний аналіз між ранньою (I та II ступінь за M. Stolte) та пізньою (III та IV ступінь за M. Stolte) стадією фіброзу ПЗ.

Морфологічні ознаки активного запалення паренхіми П3, для яких була характерна інфільтрація нейтрофільними лейкоцитами, спостерігали у 44,2\% хворих з ХП, а ознаки неактивного запалення, для яких була характерна лімфоцитарна інфільтрація - у 55,8\% хворих з ХП.

Порівняння показників ЕЗХ нормальної ПЗ і ПЗ при ХП з даними гістологічного дослідження біоптатів ПЗ, отриманих під час операції, показало достовірне збільшення жорсткості тканини $(\mathrm{p}<0,05)$ головки, тіла і хвоста ПЗ при ХП - $(8,65 \pm 1,43),(7,31 \pm 0,64)$ та $(8,19 \pm 0,96)$ кПа відповідно, тоді як за нормальної ПЗ ці показники становили $(4,05 \pm 0,33),(3,86 \pm 0,46)$ та $(3,73 \pm 0,53)$ кПа відповідно.

Рання та пізня стадії фіброзу ПЗ при ХП характеризувалась достовірною різницею між активним та неактивним запаленням тільки в головці ПЗ - збільшення показників жорсткості в 1,3 (p < 0,05) та 1,7 (p < 0,05) разу відповідно. На пізній стадії фіброзу ПЗ за допомогою ЕЗХ встановлено достовірне збільшення показників жорсткості в головці П3 - в 2,2 разу ( $<$ 0,05) та в тілі П3 - в 1,3 разу $(\mathrm{p}<0,05)$. Величина жорсткості паренхіми ПЗ позитивно корелювала з нерівністю їі контурів (r=0,889; p=0,04).

Проведенням ROC-аналізу отриманих даних встановлено високу якість діагностичної моделі оцінки стадії фіброзної трансформації анатомічних відділів ПЗ при ХП за допомогою Е3Х, оскільки середній показник AUC щодо головки ПЗ дорівнював 0,843 (95\% довірчий інтервал - ДІ 0,619-0,963; p < 0,0005). Порогове значення середніх показників ЕЗХ головки ПЗ становило 7,05 кПа. За показниками вище зазначеного порогового рівня діагностували пізню стадію фіброзу ПЗ при ХП. Чутливість, специфічність, прогностичність позитивного результату (ППР) і прогностичність негативного результату (ПНР) становили 83,3, 88,9, 90,0 і 80,0\% відповідно.

Висока якість діагностичної моделі продемонстрована щодо показників Е3Х тіла ПЗ: AUC=0,748 (95\% ДІ 0,5310,901; $<$ 0,0279). Порогове значення середніх показників Е3Х тіла ПЗ було 6,80 кПа. За показниками вище зазна- 
ченого порогового рівня діагностували пізню стадію фіброзу ПЗ при ХП. Чутливість, специфічність, ППР і ПНР становили 81,8, 76,9, 74,9 і 83,3\% відповідно.

Проведенням ROC-аналізу показників E3X, за якими оцінювали активність запалення на тлі фіброзної трансформації ПЗ при ХП, також встановлена висока якість діагностичної моделі. Так, відмінність активного запалення від неактивного на ранній стадії фіброзу ПЗ характеризувалась показником AUC, який дорівнював 0,727 (95\% ДІ 0,513-0,884; $\mathrm{p}=0,003)$.

На ранній стадії фіброзу ПЗ (AUC=0,727, 95\% ДІ 0,5130,884; $>$ < 0,01) порогове значення середніх показників запалення в ПЗ при ХП становило 4,46 кПа. За показниками вище зазначеного порога діагностували активне запалення. Чутливість, специфічність, ППР і ПНР становили 73,3, 80,0, 84,6 і 66,6\% відповідно. На пізній стадії фіброзу П3 (AUC=0,972, 95\% ДІ 0,759-1,000; $<$ < 0,0001) порогове значення середніх показників активного запалення було 9,05 кПа. Чутливість, специфічність, ППР і ПНР становили 87,5, 100,0, 100,0 і 90,0\% відповідно.

Встановлено, що нормальна ПЗ без ознак фіброзу мала показники жорсткості $(3,88 \pm 0,43)$ кПа і блакитний колір за умови налаштування приладу в діапазоні шкали жорсткості від 0 до 60 кПа.

\section{Обговорення}

Порівнянням даних ЕЗХ і результатів гістологічного дослідження біоптатів ПЗ у хворих з ХП визначено кольоровий патерн та кількісні інтервали показників жорсткості для характеристики стадії фіброзу ПЗ на тлі активності іі запалення. За наявності синьо-блакитного кольору і показників жорсткості вище 4,46 кПа діагностують ХП у ранній стадії фіброзу на тлі неактивного запалення паренхіми ПЗ; блакитно-зеленого кольору і показників жорсткості в діапазоні 4,47-7,05 кПа - ХП у ранній стадії фіброзу на тлі активного запалення паренхіми ПЗ; зелено-жовтого кольору і показників жорсткості в діапазоні 7,06-9,04 кПа - ХП у пізній стадії фіброзу на тлі неактивного запалення паренхіми ПЗ; жовто-червоного кольору і показників жорсткості вище 9,05 кПа - ХП у пізній стадії фіброзу на тлі активного запалення паренхіми ПЗ (Пат. UA № 110869).

Таким чином, визначені найбільш достовірні цифрові показники ЕЗХ активності запалення та стадії фіброзної трансформації ПЗ при ХП.

\section{Висновки}

Метод транскутанної Е3Х можливо використовувати для неінвазивної оцінки морфологічних змін ПЗ при ХП.

\section{Підтвердження \\ Фінансування}

Це дослідження є фрагментом планової НдР.

Фінансування за рахунок держбюджеу.

Внесок авторів

Всі автори внесли однаковий внесок у цю роботу. Всі ав-

тори прочитали і схвалили остаточний варіант рукопису.

\section{Конфлікт інтересів}

Автори, які взяли участь в цьому дослідженні, декларують відсутність конфлікту інтересів щодо цього рукопису.

\section{Згода на публікацію}

Всі автори дали згоду на публікацію цього рукопису.

\section{References}

1. Kawada N, Tanaka S, Uehara H, Takakura R, Katayama K, Fukuda J, et al. Potential use of point shear wave elastography for the pancreas : a single center prospective study. Eur J Radiol. 2014 Apr;83(4):620-4. doi: 10.1016/j.ejrad.2013.11.029. Epub 2013 Dec 27.

2. Ophir J, Céspedes I, Ponnekanti H, Yazdi Y, Li X. Elastography: a quantitative method for imaging the elasticity of biological tissues. Ultrason Imaging. 1991 Apr;13(2):111-34. doi:10.1177/016173469101300201.

3. Dynnyk OB, Zhajvoronok MM, Kobylyak NM, Harchenko MC. Ultrazvukova elastografiya: teoriya i praktyka stvorennya navchalnogo trenazhera. Promeneva diagnostyka, promeneva terapiya. 2014;(3):4253. [In Ukrainian].

4. Sandrin L, Fourquet B, Hasquenoph JM, Yon S, Fournier C, Mal F, et al. Transient elastography: A new non-invasive method for assessment of hepatic fibrosis. Ultrasound Med Biol. 2003 Dec;29(12):1705-13.

5. Uchida H, Hirooka Y, Itoh A, Kawashima H, Hara K, Nonogaki K, et al. Feasibility of tissue elastography using transcutaneous ultrasonography for the diagnosis of pancreatic diseases. Pancreas. 2009 Jan;38(1):1722. doi: 10.1097/MPA.0b013e318184db78.

6. Săftoiu A, Vilmann P, Gorunescu F, Janssen J, Hocke M, Larsen M, et al. Accuracy of endoscopic ultrasound elastography used for differential diagnosis of focal pancreatic masses: a multicenter study. Endoscopy. 2011 Jul;43(7):596-603. doi: 10.1055/s-0030-1256314.

7. Park MK, Jo J, Kwon H, Cho JH, Oh JY, Noh MH, et al. Usefulness of acoustic radiation force impulse elastography in the differential diagnosis of benign and malignant solid pancreatic lesions. Ultrasonography. 2014 Jan;33(1):26-33. doi: 10.14366/usg.13017.

8. Kuwahara T, Hirooka Y, Kawashima H, Ohno E, Sugimoto H, Hayashi D, et al. Quantitative evaluation of pancreatic tumor fibrosis using shear wave elastography.. Pancreatology. 2016 Nov-Dec;16(6):1063-1068. doi: 10.1016/j.pan.2016.09.012

9. Kuwahara T, Hirooka Y, Kawashima H, Ohno E, Ishikawa T, Yamamura $\mathrm{T}$, et al. Usefulness of shear wave elastography as a quantitative diagnosis of chronic pancreatitis. J Gastroenterol Hepatol. 2018 Mar;33(3):756761. doi: $10.1111 /$ jgh. 13926.

10. Gal'perin Je. I. Classification of chronic pancreatitis: determination of severity, choice of method of treatment and necessary operation. Annaly hirurgicheskoy hepatologii. 2013; 18(4):83-92. [In Russian].

11. Barannyk JeO, Lins'ka GV, Dynnyk O B, Marusenko AI. Artefakty ta metodychni pomylky zsuvnohvyl'ovoji elastografiji. Promeneva diagnostyka, promeneva terapiya. 2015;1:61-71. [In Ukrainian].

12. Morgenroth K, Kozuschek W. Pancreatitis. Berlin-New York: Walter de Gruyter; 1991. 120 p.

Отримана 01.10.2018 